\title{
Assessment (Teaching Report Portfolio) of English for Young Learners Courses
}

\author{
Dian Susyla and Ria Angraini \\ Muhammadiyah University of Bengkulu \\ angraini_ria517@yahoo.co.id
}

\begin{abstract}
The aim of this research is to find out and describe the weaknesses and strengths of the portfolio assessment of EYL courses made by English students of Muhammadiyah University of Bengkulu. This research was designed by using a descriptive method. The object of this research was eighteen portfolio assessment of EYL courses made by English students of UMB. The data were collected by using documentation technique. In analyzing the data, the rubric of Carey (2001) was used by the researchers. The result of the research shows that there were some weaknesses and strengths in the assessment (Teaching Report Portfolio) of EYL courses made by English students of UMB. There were $5.6 \%$ criteria that were not included in Teaching Report Portfolio, 39.1 \% Teaching Report Portfolio that had to be revised, and $55.3 \%$ criteria that were good. It can be concluded that there were some weaknesses. Meanwhile, the strengths of the portfolio assessments of EYL courses made by English students of UMB were an evaluation for them particularly in managing a course, being an edupreneur and creative teacher.
\end{abstract}

Keywords: Assessment, Teaching Report Portfolio, EYL, English Students' courses

\section{INTRODUCTION}

Learning English is a developmental process that occurs over a period of years. It is dependent on the comprehensibility, quality, and sustainability of language and content learning experiences (Haynes, 2010, p.2). English for young learners as one of English learners also develop their learning process in a period of year. Young language learners are those who are learning a foreign or second language and who are doing so during the first six or seven years of formal schooling. In the education systems of most countries, young learners are children who are in primary or elementary school. In terms of age, young learners are between the ages of approximately five and twelve (McKay, 2006,p.1). According to Suyanto (2007, p.15), the young learners are the students who learn English at an Elementary school. They are the students who still young in learning English. Their age is about 612 years old, which divided into two groups; young group (6-8-year-old) and older group (9-12-year-old).

In teaching English for young learners, teachers have to be creative and understand their students. Liao (2007, p.14) says that teachers' understanding of how children learn English will determine their philosophy of teaching, teaching styles, methods, and classroom management techniques. In terms of these teachers' reported teaching methods and techniques, the majority considered the use of different methods and techniques such as role-play, games, songs, multimedia equipment and the use of multiple assessments to be essential.

With regard to assessment, it is generally used to measure students' performance, diagnose the problems and measure the progress students make (Harris \& McCann, 1994, p.2). Furthermore, Vásquez., Hansen, \& Smith (2010, p.158) add that English language learners can benefit from alternative and performance assessments such as presentations, dramatic activities, projects, and portfolios.

A portfolio of creative work might include one or two items created specifically for assessment purposes, some regular class assignments, and some items created outside a school setting (Starko, 2010, p.300). According to O'Malley \& Pierce (1996, p.12) portfolio focused collection of student work to show progress over time with some advantages such as integrates information from a number of sources, gives the overall picture of student performance and learning, strong students involvement and commitment, and calls for student self-assessment. The portfolio has been one of the assessments that can be used by the teacher and learner in teaching and learning English. In portfolio assessment, students and teachers become partners who confer on portfolio contents and their interpretation (O'Malley \& Pierce,1996, p. 34). Portfolios have caught the attention of educators as a way of evaluating students' progress through an extended period of time. Portfolios are purposeful collections of students' work which document student learning or in a word of an assessment researcher "produce a portrait" of a student. Portfolios are an effective means of assessment because they build students' metacognitive awareness in that they help children recognize their own strengths and weaknesses Gordon (2007, p. 209).

In line with the aforementioned explanation, English students in Muhammadiyah University of Bengkulu that took English for Young Learners subject have to collect portfolio assessment. Particularly in teaching learning for young learners, they were given various skills that needed for successful managing English class for elementary school. They were given knowledge about young learners characteristics and the ways of teaching-learning, making English teaching media, teaching English for young learners by using games, songs and music, classroom management, teaching English inside and outside the classroom.The students have to plan to have and open 
private English course that can be the place for them practicing some activities of EYL lesson. All of those activities had to be prepared, made, and reported in the form of portfolio assessment (teaching report portfolio) of English for young learners courses. Shute, \& Becker (2010, p. 229) argue that needed careful attention from assessment experts, measurement professionals, teachers, principals, learning scientists and many others if the field is to move forward to develop better assessments that promote learning as well as provide fair means of accountability for students, teachers, and schools. The assessment must capitalize on advances in technology, it is a contextualized, social activity, and must serve teaching and learning.

In accordance with the statement above, the researchers conducted this research in attempting to find out and describe the weaknesses and strengths of the assessment (Teaching Report Portfolio) of EYL courses made by English students of Muhammadiyah University of Bengkulu.

\section{METHODS}

This research was designed by using a descriptive method. Gay (1990) explains that descriptive research involve collecting data in order to test hypotheses or to answer questions concerning the current status of the subject of the study and the descriptive researcher can only measure what already exists. The object of this research was eighteen assessments (Teaching Report Portfolio) of EYL courses made by English students of Muhammadiyah University of Bengkulu. Those portfolios were made by
English students at sixth semester in Academic Year 2015/2016, particularly that had taken English for Young Learner subject and had EYL Courses. The data were collected by using documentation technique. The researchers analyzed the weaknesses and strengths of the portfolio assessment by using the rubric of Carey (2001). According to Carey (2001), an effective portfolio is not simply chronological collections of students' work from particular time. Rather, their design should enable illustration of students' status at the outset of instruction and provide documentation of their progress through instruction. There are some criteria that can be used in making or designing the portfolio, it is designed by using a rubric as follows;(1) Selecting a container for the portfolio. Several criteria should be considered for selecting portfolio contents or containers that best suit the students' needs. (2) Entering information on the summary form and placing products into the portfolio. Problematic areas in students work samples might be positively described as skills that need improvement, future focus, or strengthening. (3) Computer technology.

\section{RESULT AND DISCUSSION}

The result of the research showed that there were some weaknesses and strengths in the assessment (Teaching Report Portfolio) of EYL courses made by English students of Muhammadiyah University of Bengkulu.There were $5.6 \%$ criteria that were not included in Teaching Report Portfolio, $39.1 \%$ Teaching Report Portfolio that had to be revised (needs work), and $55.3 \%$ criteria that were good.

Table 1: The percentage criteria of English Students' Courses (Teaching Report Portfolio)

\begin{tabular}{|c|c|c|c|c|c|c|c|}
\hline \multirow{3}{*}{ No } & \multirow{3}{*}{$\begin{array}{l}\text { (Teaching } \\
\text { Report } \\
\text { Portfolio) } \\
\text { Of English } \\
\text { Students' } \\
\text { Courses }\end{array}$} & \multicolumn{6}{|c|}{ Criteria } \\
\hline & & \multicolumn{2}{|c|}{$\begin{array}{l}\text { Not } \\
\text { Included }\end{array}$} & \multicolumn{2}{|c|}{$\begin{array}{l}\text { Needs } \\
\text { Work }\end{array}$} & \multicolumn{2}{|c|}{ Good } \\
\hline & & $\mathbf{F}$ & $\%$ & $\mathbf{F}$ & $\%$ & $\mathbf{F}$ & $\%$ \\
\hline 1 & A Line Course & - & - & 11 & $2.5 \%$ & 13 & $3 \%$ \\
\hline 2 & Al-Fafa Course & 1 & $0.2 \%$ & 8 & $1.9 \%$ & 15 & $3.5 \%$ \\
\hline 3 & $\begin{array}{l}\text { Bengkulu } \\
\text { English Course }\end{array}$ & 7 & $1.8 \%$ & 8 & $1.9 \%$ & 9 & $2.0 \%$ \\
\hline 4 & Bright Course & - & - & 10 & $2.3 \%$ & 14 & $3.2 \%$ \\
\hline 5 & Brosist Course & - & - & - & - & 24 & $5.5 \%$ \\
\hline 6 & Bubble Course & 2 & $0.4 \%$ & 15 & $3.5 \%$ & 7 & $1.7 \%$ \\
\hline 7 & $\begin{array}{l}\text { Camkoha } \\
\text { Course }\end{array}$ & 3 & $0.6 \%$ & 13 & $3 \%$ & 8 & $1.9 \%$ \\
\hline 8 & $\begin{array}{l}\text { Do } \quad \operatorname{Re} \quad \mathrm{Me} \\
\text { Course }\end{array}$ & 1 & $0.2 \%$ & 11 & $2.5 \%$ & 12 & $2.7 \%$ \\
\hline 9 & Eiffell Course & - & - & 8 & $1.9 \%$ & 16 & $3.7 \%$ \\
\hline 10 & Five Course & - & - & 9 & $2.0 \%$ & 15 & $3.4 \%$ \\
\hline 11 & Gading Course & 5 & $1.2 \%$ & 9 & $37 \%$ & 10 & $2.3 \%$ \\
\hline 12 & Genius Course & 5 & $1.2 \%$ & 8 & $1.9 \%$ & 11 & $2.5 \%$ \\
\hline 13 & Golden Course & - & - & - & - & 24 & $5.5 \%$ \\
\hline 14 & Ideal Course & - & - & 14 & $3.2 \%$ & 10 & $2.3 \%$ \\
\hline 15 & $\begin{array}{l}\text { Kalpataru } \\
\text { Course }\end{array}$ & - & - & 11 & $2.5 \%$ & 13 & $3 \%$ \\
\hline 16 & Kejora Course & - & - & 12 & $2.7 \%$ & 12 & $2.8 \%$ \\
\hline 17 & Key Course & - & - & 11 & $2.5 \%$ & 13 & $3 \%$ \\
\hline 18 & $\begin{array}{l}\text { Metamorphose } \\
\text { Course }\end{array}$ & - & - & 11 & $2.5 \%$ & 13 & $3 \%$ \\
\hline & Total & 24 & $5.6 \%$ & 169 & $39.1 \%$ & 239 & $55.3 \%$ \\
\hline
\end{tabular}


Based on the data Table 1 above, there were seven Teaching Report Portfolios from different English Students' Courses that did not make the criteria based on the rubric of Carey or $24(5.6 \%)$ criteria were not included.

Meanwhile, there were sixteen Teaching Report Portfolios of English Students' Courses that have to be revised or $169(39.1 \%)$ criteria were needed works. In other words, there were two Teaching Report Portfolios of English Students' Courses that did not need revise criteria on the rubric of Carey because they had been made and completed all of the criteria on their Teaching Report Portfolios of English Students' Courses.

Furthermore, there were $239(55.3 \%)$ good criteria in Teaching Report Portfolios of English Students' Courses based on Carey's rubric. From eighteen English Students' Courses, there were two courses that had completed 24 good criteria based on the rubric of Carey. They were Brosist course and Golden Course. Both of them did not need revisions.

\section{Discussion}

3.1.1 The Weaknesses of Assessment (Teaching Report Portfolio) of EYL Courses Made by English Students of Muhammadiyah University of Bengkulu

Looking at the result from the table and calculations above, there were some weaknesses on assessment (Teaching Report Portfolio) of EYL courses made by English students Muhammadiyah University of Bengkulu. It could be seen from three aspects i.e. "not included, needs work, and good" that had been analyzed by the researchers. The researchers had found out the criteria that weren't included in the portfolio (the mean score 5.6\%), the "needs work" aspect were $39.1 \%$, meanwhile for "good" aspect were $55.3 \%$. Most of the weaknesses of assessment (Teaching Report Portfolio) of EYL courses that had been made by the English students of Muhammadiyah University of Bengkulu were they did not take note from the teachers after teaching-learning process in their courses, so that they did not get and give information toward students' progress in the enabling skills and goal over the time period.The English students only put the recapitulation of students grade without giving commentary such as what the students had done in the activity, what the dominant problem and difficulty that were founded by them, how the way and solution to overcome them, and how the students' progress before and after the meeting. The researchers found that were only some portfolios which explained about their progress. Besides that, the weaknesses of those portfolios were related to criteria number 9,10 and 13. The weaknesses of assessment (Teaching Report Portfolio) of EYL courses that had been made by the English students of Muhammadiyah University of Bengkulu were; (a) the English students did not Include type of test (readiness, pretest, practice, or posttest), (b) did not Include criteria used for scoring each exhibit, and (c) did not describe enabling skills that needed by the students. The researchers found out that almost $77 \%$ criteria that were not included in assessment (Teaching Report Portfolio) of EYL courses that had been made by the English students of Muhammadiyah University of Bengkulu were caused by lack of knowledge on preparing and making tests. Moreover, assessment (Teaching Report Portfolio) of EYL courses that had been made by the English students of Muhammadiyah University of Bengkulu required English students and Lecturer commitments, time, and knowledge in planning and managing assessment. O'Malley and Pierce (1996, p. 34) suggest that in portfolio assessment, students and teachers become partners who confer on portfolio contents and their interpretation. In fact, there were two portfolios namely Brosist course and Golden course that included all of the good criteria on the portfolio commonly. Both of portfolios reached $100 \%$.

\subsubsection{The Strengths of Assessment (Teaching Report} Portfolio) of English for Young Learners Courses Made by English Students of Muhammadiyah University of Bengkulu

The researcher found that a half of total students' portfolio assessment had different creativity and management course particularly in covering and collecting. It could be seen from the material and kinds of casing and paper that used such as lantung, panel, binder, etc. So, that the portfolios were different from one to the other. The Strengths of Assessment (Teaching Report Portfolio) of English for Young Learners Courses Made by English Students of Muhammadiyah University of Bengkulu could be seen from criteria no 2 that Attractive; games, song, fun activities that conducted by them and proved by documentation and portray a chronology of development and photos of activities or students' photos and video activities on the outside class such as outbound, constructing the instructional media creatively, making English song for young learners that was made individually and also games that were made by teamwork or group. The researchers found that there was new in assessment (Teaching Report Portfolio) of English for Young Learners Courses made by English Students of Muhammadiyah University of Bengkulu. It was the financial report. The strengths of the portfolio were related to the advantages of portfolio assessment themselves. The portfolios of English student had fulfilled the standardization because some indicators portfolio assessment related to it. The portfolio is evident about many activities that have been done by the English students in EYL' s subject. The strengths of assessment (Teaching Report Portfolio) of English for Young Learners Courses made by English Students of Muhammadiyah University of Bengkulu were being one of evaluations for them particularly in managing a course, being edupreneur and creative teacher because they have to look for a way to build and maintenance their courses without using much money even though they could earn some money by opening a course. They have to build sense of belonging 
and edupreneurship in attempting to face and overcome the problems in teaching learning English. Venn (2000, p. 538) stated that portfolio assessment can make the students more active, creative, and give chance for them to improve their ability in study and students opportunity to have extensive input into the learning process.

\section{CONCLUSION}

It can be concluded that there were some weaknesses in the assessment (Teaching Report Portfolio) of EYL courses made by English students of Muhammadiyah University of Bengkulu. Some weaknesses that found in portfolio assessment of EYL courses such as did not take note every evaluation from the teachers after teachinglearning process in their courses, did not Include type of test (readiness, pretest, practice, or posttest), did not Include criteria used for scoring each exhibit, and did not describe enabling skills where student needs. Meanwhile the strengths of the assessment (Teaching Report Portfolio) of EYL courses made by English students of Muhammadiyah University of Bengkulu were attractive; games, song, fun activities that conducted by them and proved by documentation, using technology and portray a chronology of development and photos of activities or students' photos and video activities on the outside class such as outbound, constructing the instructional media creatively, making English song for young learners that was made individually and also games that were made by teamwork or group. Those were the evaluation for them particularly in managing a course, being the edupreneur and creative teacher. Carey (2001) states that effective portfolio is not simply chronological collections of students' work from particular time. Rather, their design should enable illustration of students' status at the outset of instruction and provide documentation of their progress through instruction.

\section{REFERENCES}

Carey, L. (2001). Measuring and Evaluating School Learning.USA: Addison-Western Publishing.

Gay.L.R. (1990). Educational Research Competencies for Analysis and Application. New York: Macmillan Publishing Company.

Gordon, T. (2007). Teaching Young Children a Second Language. The United States of America: An imprint of Greenwood Publishing Group, Inc.

Harris, M.,\& McCann, P. (1994). Handbooks for the English Classroom Assessment. Oxford: Macmillan Publishers Ltd.

Haynes, J.,\& Zacarian, D. (2010). Teaching English Language Learners Across The Content Areas. Alexandria, Virginia USA: ASCD.

Liao, P. (2007). Teachers' Beliefs about Teaching English to Elementary School Children. Taipei: National Taipei University.
McKay, P. (2008). Assessing Young Language Learners. New York: Cambridge University Press.

O’Malley,J. M., \& Pierce, L. V. . (1996). Authentic Assessment for English Language Learners. Practical Approaches for Teachers. The United States of America: Addison-Wesley Publishing Company, Inc.

Shute, V. J. \& Becker, B. J. . (2010). Innovative Assessment for the 21st Century-Supporting Educational Needs. New York: Springer Science+Business Media.

Starko, A. J. (2010). Creativity in the Classroom.Schools of Curious Delight. New York: Routledge.

Suyanto, K. (2007). English for Young Learners. Jakarta: Bumi Aksara.

Vásquez, A., Hansen, A. L., \& Smith, P. C. (2010). Teaching Language Arts to English Language Learners. New York: Routledge. 